\title{
Educational Networking as Key Factor of Specialist Training in Universities
}

\author{
Ernst Raisovich Safargaliev ${ }^{1} \&$ Vladislav Lvovich Vinogradov ${ }^{2}$ \\ ${ }^{1}$ Elabuga Institute of Kazan Federal University, Russia \\ ${ }^{2}$ Branch of Kazan Federal University in Elabuga, Russia \\ Correspondence: Ernst Raisovich Safargaliev, Kazan (Volga Region) Federal University Branch in Elabuga, \\ Elabuga, Republic of Tatarstan, 423600, Russia. Tel: 7-937-291-5657. E-mail: safargaliyeva@mail.ru
}

\author{
Received: March 23, 2015 Accepted: April 25, 2015 Online Published: September 28, 2015 \\ doi:10.5539/ies.v8n10p200 URL: http://dx.doi.org/10.5539/ies.v8n10p200
}

\begin{abstract}
The paper considers the problems of science and education space and network formation between business and education. The productive form of integration between the parties is revealed. The authors address employment as an evaluation criterion for networking between university and business. Special emphasis is on active training methods as a way to develop the student's personality. The paper data is sourced from a survey conducted on university students.
\end{abstract}

Keywords: active training methods, employment, environment monitoring, graduate, motivation, networking

\section{Introduction}

Amidst dynamic development of industries, which necessitates relevant changes in education, the problem of building common science and education space "university-business" becomes actual. Building of this space involves transition from traditional forms of social partnership to networking, where a few social functions can be supposedly shifted onto the partner's organization. Thus, it creates an effective mechanism for commissioning of progressive ideas that meet the demands of innovation-driven economy. Moreover, it strengthens the placement-oriented components of professional education. To improve the quality of education so that it would echo the level of scientific and technical development of the society has always been a primary aim of educational system. Today networking is also defined as organizing of extensive partnership and connections that ensure availability, quality and effectiveness of educational services and that guarantee the usage of up to date innovative technologies (Medvedev \& Skripnichenko, 2011).

The studies of interrelations between universities, businesses, schools, scientific centres reveal a wide variety of integration forms for science, education and business (Minina, Basov, \& Demidova, 2012). At the same time, bi-lateral integration traditionally dominates: science-business, education-business. Networking allows for more diverse and productive forms of integration between the parties.

The literature survey reveals that external integration of education is mostly developed in the works of Abankina, Gubarkov, Egorshin, Knyazev, Kuzninov, Maltseva, etc. The points of view of the following foreign and Russian scientists on structural integration and interaction have been analysed in this study: Porter, Williamson, Avdasheva, Vikhansky, Dementyev, Kleiner, Lunkin, Ponomarev, Rumyantsev, etc. The works of Demetyev, Kleiner, Knyazev, Klyuev, Ratner, Rumyantseva, and Shereshev have been studied in connection with networking management.

It should be noted here that the least developed subject in the Russian scientific literature is internal mechanisms of educational networking.

\section{Method}

In February 2014, a social research among the graduates of Naberezhnye Chelny affiliate of Kazan Federal University was carried out. It had the following objectives: define the share of graduates placed into jobs, assess their knowledge, degree of their satisfaction with qualifications obtained and find prospects of further education. Telephone survey was used as a research method as it allowed covering most graduates of 2013. It should be noted that the research data help us assess the level of educational networking in the city of Naberezhnye Chelny. 


\section{Results}

Currently, teachers at professional educational institutions have the task to arrange the conditions that would enable their students to absorb as much knowledge as possible in such a short time as possible and to acquire the skills of how to constructively use this knowledge in the real world. In our opinion, the following would contribute to it:

- Stimulating students' interest in learning: not for the sake of a diploma, but for the sake of consistent and up to date knowledge based on practice. The students' motivation is one of the most effective ways to improve the process and results of learning, while motives are the driving force of the process of learning and material absorption (Mormuzheva, 2013). Active methods of teaching promote the student's personal development and self-development, involve them in realistic problem solving, and widen their knowledge and skills. Referring your students to associatebusinesses can also be one of the incentives to study well.

- Building strategic partnership between University and Business - manufacturer and consumer of specialists. Here we would have to make sure that the competencies the graduates have acquired meet the needs of the age and the graduate is in demand. In this case, the learning process would fuse teaching, actual practice, and scientific work of the student. If University and Business joined their efforts, it would help to eliminate staff scarcity and businesses would be able to apply for required specialists in advance.

- University having a directing role in keeping track of the labour market situation would help to have most effective networking with Business. University would optimally solve the problems related to independent monitoring of educational processes and the graduates' state of being in demand in the employment market. In summary, integration of education and business is possible if interests and objectives of the parties are coherent.

\section{Discussion}

The research has revealed that out of 453 graduates of $2013,76.2 \%$ of the respondents has found employment, $23.9 \%$ has failed to get a job. However, $7.5 \%$ of the respondents do not work due to the external reasons: $3.3 \%$ of them are in the army, $4.2 \%$-on maternity leave. In total, $16.3 \%$ of the graduates have failed to find a job. And they are the graduates of the most sought after university in the city.

Only $49.2 \%$ of the graduates have managed to get a job that matches their qualifications. $26.9 \%$ has found employment that does not match their degree (See Figure 1).

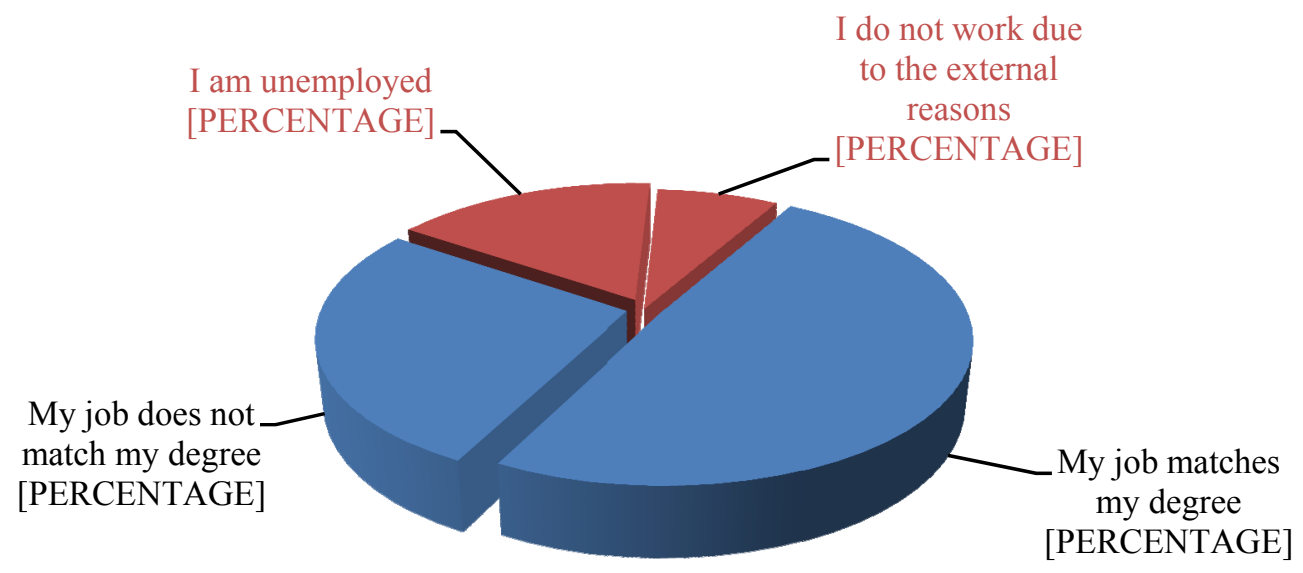

Figure 1. Share of Employed Graduates (\%)

In our opinion, the reason for such a high percentage of unemployed graduates lies with the way students treat their profession, i.e. the objectives of university studies. The correct career goal defines the objective of university studies. One of the primary reasons why modern graduates often get jobs that do not match their qualifications lies with the fact that the choice they make when applying for a university course is not quite conscious or accurate. Sometimes the applicant does not quite understand what they really like or want. During their university years the student re-evaluates their choice and it often makes them reject their selected 
professional development path (Gee, 2010).

Students see their studies as a way to achieve their goals. It constitutes one of the levels of goal-oriented base of activities - motivation of professional activities. The degree of motivation enables us to judge students' vocational aptitude. Some students study better, some worse because they want (or do not want) to obtain new knowledge and find fulfillment in cognition, earn more, assert themselves and gain a footing in society and in their social surrounding (Malinauskas, 2005).

Professional motivation is an internal force driving the development of professional competence and personality. It is the foundation for effective development of professional education and personal culture (Gordashnikov \& Osin, 2009).

Changes taking place in human activities bring about new requirements to the organization and quality of professional education (Safargaliev, Eremina, Savitsky, \& Camelina, 2015). Modern graduate of professional educational institution must not only possess special knowledge and skills, they also must feel a need to achieve and succeed; they must know that they will be in demand on the labour market. It is essential to make the students of professional educational institutions interested in knowledge accumulation, independence and continuous self-education. To achieve these goals, students must have motivation to learn.

For students to truly get into the swing of things, the objectives, which they are set during their university years, must not only be clear but mentally accepted by them. In other words, they must have value for students. As the true motivation source is in the person itself, they ought to want to do something and do it. That's why the governing motive of learning is inner momentum.

The student will have a wish to study and will do so, only if it interests and attracts them. They need cognitive motives (Koinova-Tselner, 2014). The students of professional educational institutions get to know their selected occupation much better when they do placements or laboratory research. They feel challenged and motivated to gain further theoretical knowledge as they are aware that they can use it in life. Eventually, business gets into coordination with university not only after student's graduation, but also when they gain new knowledge. Thus, the conditions for accommodation of interests, exchange and distribution of resources are envisaged.

The survey has revealed the main reasons why graduates cannot find a job matching their degree. The main reason is the lack of such jobs (39.2\%). Then lack of experience (13.4\%), low wages (12.3\%). Nearly every tenth graduate (11.3\%) noted that they got a job that did not match their degree because the placement they did at university helped them realize that their trade is not currently in demand and that they have more prospects in other trades (See Figure 2). 
No jobs matching my degree

Job experience required

Job matching my degree is low paid

I got a job not matching my degree after: doing placement

I do not wish to work

Temporary job, placement

I have got a job matching my first degree

I have got my own business

I do not like my chosen trade

Other
7

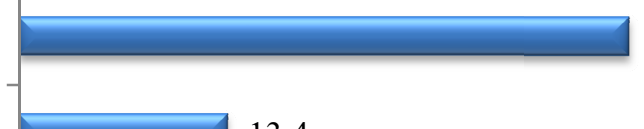

13.4
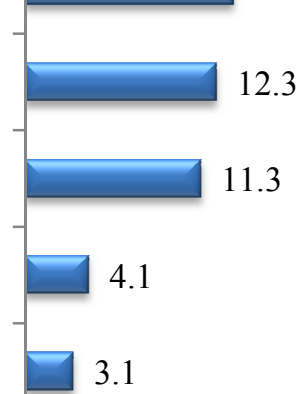

12.3

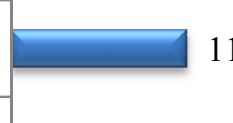

11.3

3.1

2.1

2.1

2.1

10.3

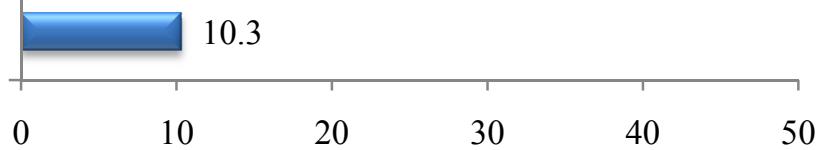

Figure 2. Why graduates get jobs that do not match their degree (\%)

When asked "Are you going to continue working in this company?", the following answers were received: $85.7 \%$ of graduates would do so, $11.9 \%$ would pack their job, $2.4 \%$ were undecided.

Salary is not the least important matter for graduates. Most recent graduates $(62.6 \%)$ earn between 10000 and 20000 Roubles, though the average wage in Naberezhnye Chelny is 24588 Roubles (See Figure 3). 


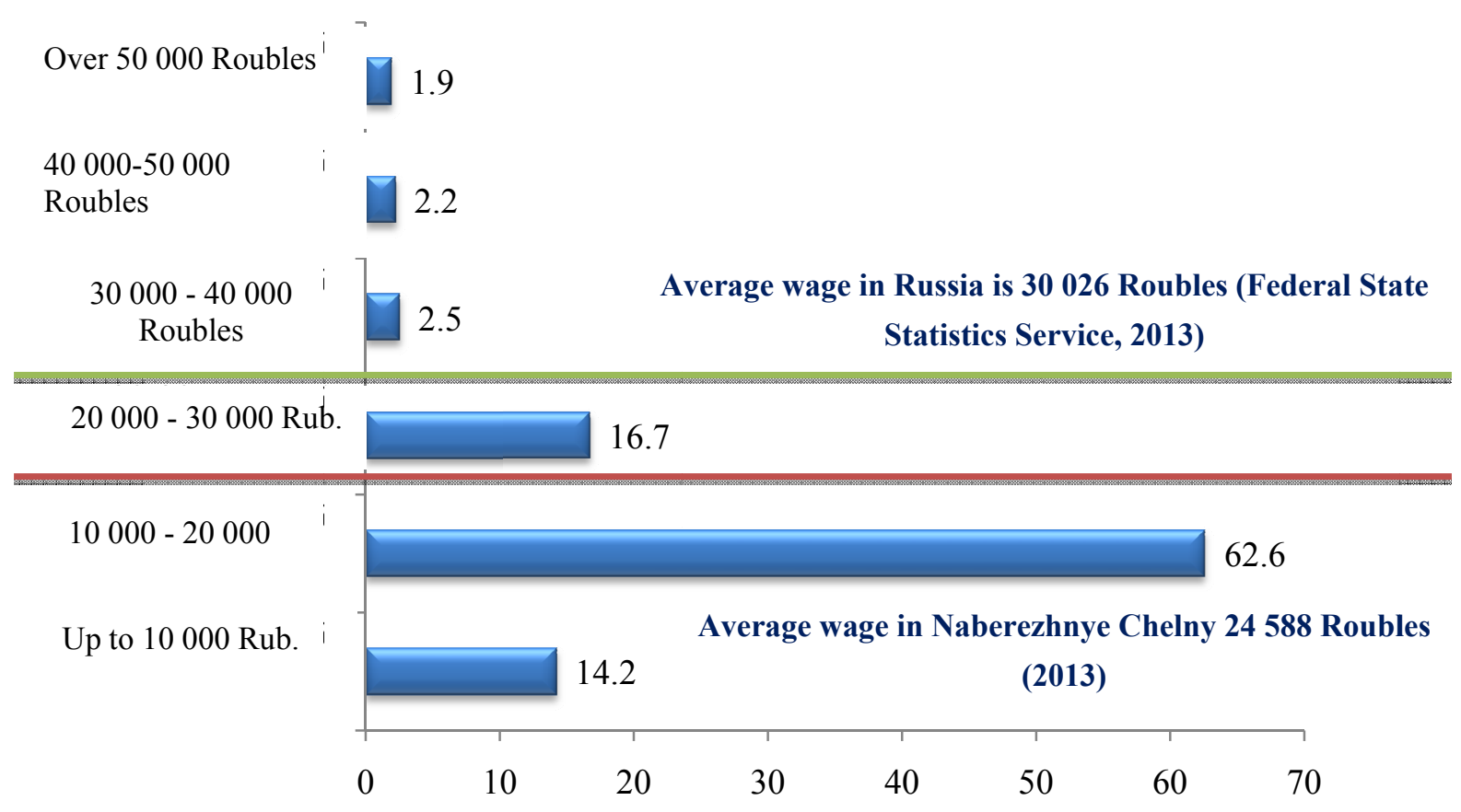

Figure 3. Average pay of graduates (\%)

University and business are two interrelated elements in the educational process: university is a manufacturer and business is a consumer of specialists in demand. So, the effectiveness of interrelation of the parties depends a lot on the feedback. And the notion of "employment" can act here as a criterion of relationship between university and business. In the real world, the information about the effectiveness of graduates' employment is often sketchy and insufficient.

As higher education is deficient in feedback between university and business, graduates face a serious problem of finding a job. Employers are interested in experienced employees. However, full-time students find it difficult to combine studies and a job matching their degree. Recent graduates are often considered as basic material to be further trained to become highly skilled specialists.

Education a graduate gets in university does not enable them to immediately get off the ground.

Employers expect recent graduates not to only have general and special knowledge, but also certain key competencies, such as computer skills, foreign languages and ability to absorb new information. In addition to the above, there should be no discontinuity between the knowledge recent graduates get in university and the work they do in company.

The survey revealed that only $68.8 \%$ of graduates of Naberezhnye Chelny affiliate of Kazan Federal University are fully satisfied with the level of professional training they received there. $20.7 \%$ of the respondents are satisfied though not fully, $6.4 \%$ of the respondents are not satisfied and $4.1 \%$ were undecided.

The competencies the respondents rated most highly are ability to work in a team (a score of 4.5 out of 5.0), ability to acquire and analyse the new information (a score of 4.5), commitment to career progress and professional development (a score of 4.4), readiness and ability to learn further (a score of 4.4) (See Table 1). 
Table 1. Satisfaction with level of professional training in university, score

\begin{tabular}{lll}
\hline 1 & Ability to work in a team & 4.5 \\
2 & Ability to acquire and analyse new information, develop new ideas & 4.5 \\
3 & Commitment to career progression and professional development & 4.4 \\
4 & Readiness and ability to learn further & 4.4 \\
5 & Computer skills & 4.3 \\
6 & Comprehensive knowledge, culture & 4.3 \\
7 & Ability to effectively present yourself and the results of your work & 4.3 \\
8 & Knowledge of areas related to chosen career & 4.1 \\
9 & Level of basic professional training & 4.1 \\
10 & People management skills & 3.9 \\
11 & Level of practical knowledge and skills & 3.8 \\
12 & Knowledge of foreign languages & 3.5 \\
\hline
\end{tabular}

University will educate specialists that are in high demand on the labour market only if it closely cooperates with businesses. And both the parties are interested in such a close cooperation. Businesses have opportunities to influence the curriculum and education process with a view of getting a "special employee". University gets a chance to track the changing requirements to specialists in different industries and to timely adjust the curricula in a climate of constantly changing innovation technologies.

Therefore, there crops up strategic partnership between University and Business, where an educational establishment trains specialists consistent with laws of development and long-term company demand forecasts. In such a case, University is actively involved and contributes to the solution of the employment problem for graduates supporting them in their job search and career building.

This system assumes continuous professional education and extensive cooperation between all educational establishments: from schools and colleges to universities. The employee's qualifications and professional competencies should have constant development. However, nearly half of the graduates of Naberezhnye Chelny affiliate of Kazan Federal University do not wish to continue their education (46.6\%). 27.5\% of the respondents intend to widen their knowledge and improve their skills in future. Nearly every fourth graduate is going to obtain further education in a different field $(25.9 \%)$.

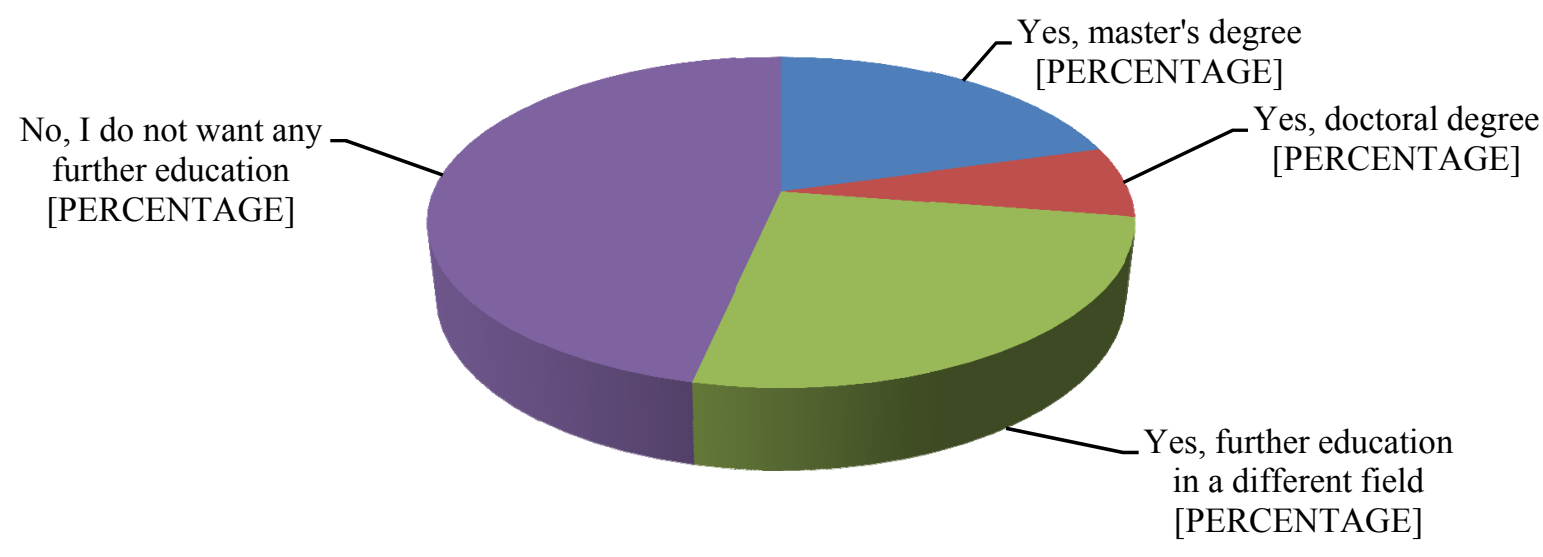

Figure 4. Graduates' wish to obtain further education (\%)

A large percentage of graduates not wishing to continue their education could be caused by the teaching methods in university. The choice of training method is linked to many factors. However, in real life students see 
monotonous teaching techniques aimed at memorization of the material under study. Quite often there is no consideration given to the age peculiarities of students; each course year could use its own teaching techniques. As a rule, a student is considered as an object accumulating knowledge and skills. However, learning is active self-modification (Novikov, 2006). Active teaching methods contribute to incremental self-modification.

Active teaching methods as compared to traditional methods have a greater impact on the educational process. This fact is supported by a research: human mind imprints up to $10 \%$ of what is heard, up to $50 \%$ of what is seen and up to $90 \%$ of what is done (Dzhalaganiya).

\section{References}

Gee, J. P. (2010). Innovative assessment for the 21st century (pp. 13-40). New York.

Gordashnikov, V. A., \& Osin, A. Ya. (2009). Education and Health of Medical Students. Akademiya Estestvoznaniya (p. 395).

Koinova-Tselner, Yu. V. (2011). Pedagogical Techniques of Active Teaching in Primary School. Bishkek.

Malinauskas, R. K. (2005). Motivation of Students of Different Years. Sotsiologicheskiye Issledovaniya, 2, 134-138. Retrieved from http://ecsocman.hse.ru/socis/msg/18009929.html

Medvedev, I. B., \& Skripnichenko, V. I. (2011). Problems of Educational Institutions Networking. Newsletter of Tomsk State Teacher Training University, 13, 239-242.

Minina, V. N., Basov, N. V., \& Demidova, I. D. (2012). Integrative Complex as a Networking Form of Science, Education and Business. Journal of Sociology and Sociological Anthropology, 5(64), 307-326.

Mormuzheva, N. V. (2013). Motivating Students of Professional Institutions. Pedagogika: Traditions and innovations: Materials of IV International Scientific Conference (Chelyabinsk) (pp. 160-163). Chelyabinsk: Dva Komsomoltsa.

Novikov, A. M. (2006). Modern Teaching Methods. Specialist, 1, 27-31.

Safargaliev, E. R., Eremina, I. I., Savitsky, S. K., \& Camelina, V. A. (2015). Mathematical Model and Qualimetric Assessment of Graduate Education Quality in Environment Saturated with Information and Communication Technologies. International Education Studies, $8(2), \quad 78-80$. http://dx.doi.org/10.5539/ies.v8n2p78

\section{Copyrights}

Copyright for this article is retained by the author(s), with first publication rights granted to the journal.

This is an open-access article distributed under the terms and conditions of the Creative Commons Attribution license (http://creativecommons.org/licenses/by/3.0/). 